\title{
MANAGERIAL FORESIGHT AND ATTEMPTED RENT APPROPRIATION: INSIDER TRADING ON KNOWLEDGE OF IMMINENT BREAKTHROUGHS
}

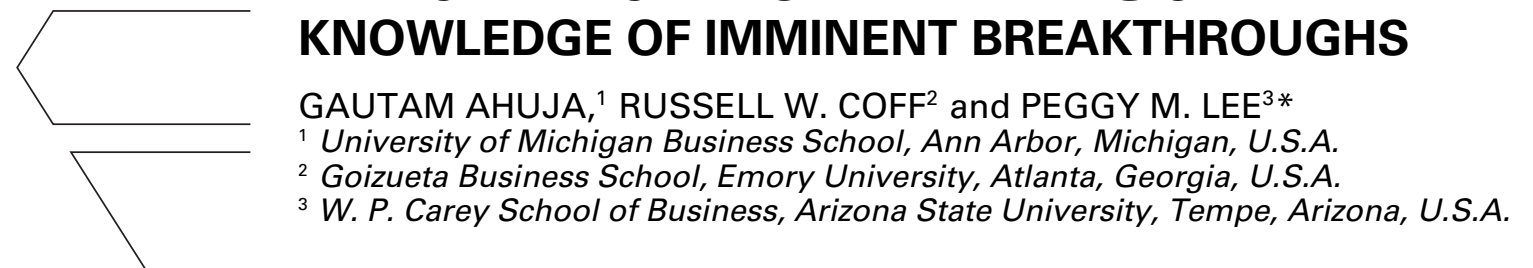

In order to establish a competitive advantage, firms must acquire or create resources at a price below their value in use. Absent pure luck, this requires managers to exercise foresight about a resource's future value and/or complementarities with pre-existing capabilities. This foresight grants managers the opportunity to exploit information asymmetries for personal gain as well as building organizational capabilities. Nevertheless, there is limited research on the extent of foresight or how managers use it. In our study of insider trading, we found that managers purchase stock well before breakthrough patents are filed. We argue for further research on the extent of managerial foresight and how it affects rent generation and appropriation. Copyright (c) 2005 John Wiley \& Sons, Ltd.

Follow the Patents? That's what one research boutique is doing - and its work suggests that investors should pay close attention to companies' patent activity ... At the core of CHI's system is something it calls 'citation impact'. (Robert Barker, BusinessWeek, 11 March 2002)

A central question raised in theories of competitive advantage is how firms acquire and/or create strategic resources for less than their value in use. Barney (1986) offers two explanations: firms have unique expectations about a new resource's value or luck (e.g., the asset's value is not anticipated). Unique expectations, in turn, stem from private information or idiosyncratic complementary assets that firms accumulate over time (Barney, 1989; Dierickx and Cool, 1989). Whether strategic

Keywords: managerial foresight; resource-based view; rent appropriation; insider trading

*Correspondence to: Peggy M. Lee, W. P. Carey School of Business, Arizona State University, Tempe, AZ, 85287-4006, U.S.A. E-mail: Peggy.Lee@asu.edu assets are acquired directly or accumulated gradually, there is an implicit assumption that managers play a key role in developing capabilities. Generally, this foresight precedes rent generation as it takes time to put new resources into productive use. Thus, resource-based competitive advantages hinge on managers' ability to identify and accumulate strategic assets over time (Amit and Schoemaker, 1993).

This study highlights two assumptions underlying the resource-based view: (1) managers possess some degree of strategic foresight; and (2) strategic foresight is used for the benefit of the firm. We argue and subsequently demonstrate that when managers have foreknowledge about strategic assets they may try to use it for personal gain by engaging in insider trading. This does not challenge the second assumption so much as it suggests that managers may use their knowledge in multiple ways. While foresight may be necessary for rent generation, it does not necessarily imply that such rents will flow, in their entirety, to shareholders. In demonstrating this, we also provide empirical 
evidence on the extent and quality of managerial foresight.

We explore managerial foresight in the context of breakthrough patents: those with a high 'citation impact,' an indication that a firm may have developed strategic assets. We argue that the patent process resembles Dierickx and Cool's (1989) asset accumulation model. For that reason, such patents are viewed as signals of future economic performance (see the quotation above). In addition, patents may serve as isolating mechanisms to keep technologies from rivals or allow firms to capture rents through licensing (Lippman and Rumelt, 1982; Teece, 1986). While patents overtly reflect codified knowledge, they also represent underlying tacit and complex knowledge critical to subsequent innovations or to commercialization (Long, 2002). Thus, implicit capabilities indicated by key patents may also be inimitable due to tacitness, causal ambiguity, or social complexity (Barney, 1991).

Information about breakthrough patents materializes at different times to different stakeholders. In the early stages of $R \& D$, knowledge is tacit and hard to convey, even within the firm (Nonaka, 1994). In preparing a patent application, some of the knowledge becomes codified and its potential becomes clearer. However, even when such knowledge is codified and the patent application is filed, information about the breakthrough may be kept in confidence until the patent is granted. Hence, information asymmetries between managers and investors (as well as rivals) may persist well after knowledge is codified in a patent application.

Empirically, we examine whether managers have the foresight to identify key patents ex ante as reflected in insider trading patterns. The following sections explore how information asymmetries arising from knowledge creation may influence insider trading. The proposed hypotheses are tested and we conclude with implications and directions for additional research.

\section{FORESIGHT, RENT APPROPRIATION, AND INSIDER TRADING}

The core question for strategy researchers is why some firms outperform others (Rumelt, Schendel, and Teece, 1991). For example, the resource-based view focuses internally on advantages conferred by unique inimitable resources. This theory has important implications for managerial foresight about the emergence of an advantage and for the ability of managers to exploit this foreknowledge.

\section{Competitive advantage and foresight}

Managerial foresight is the ability to predict how managers' actions can create a competitive advantage. As such, it plays a critical role in all major theories of competitive advantage; each of these theories implicitly assumes that managers have some degree of foresight about the emergence of an advantage. Absent foresight, these theories would, in practice, be indistinguishable from luck. Thus, if managers play a systematic role in the emergence of an advantage they must have foresight about what actions are likely to lead to an advantage.

In the case of the resource-based view, advantages either emerge through strategic factor markets (Barney, 1986) or the accumulation of idiosyncratic resources over time (Dierickx and Cool, 1989). Setting aside luck-based explanations, it is clear that managers must have some foresight that their actions may create an advantage. Barney argues that having 'more accurate' information about the value of a resource enables managers to acquire resources at a price below their ultimate value in use-assuming rival bidders lack access to the private information (Barney, 1986: 1235-1236). For example, knowing that IBM was seeking an operating system in 1981 for their new personal computer, Bill Gates acquired a $\mathrm{CP} / \mathrm{M}$ clone called 86-DOS for a mere $\$ 50,000$ - the rest is Windows history (Miller, 2001). If Seattle Computer, the original owner of DOS, had understood the potential, the selling price would have more accurately reflected the ultimate value of the asset and Gates would not have realized as much of the rent.

Similarly, Dierickx and Cool (1989) argue that firms acquire relatively generic resources in spot markets but that these are integrated and exposed to the firm's idiosyncratic routines. Over time, this path-dependent process of resource accumulation produces unique capabilities that rivals, who have distinct path dependencies of their own, cannot easily imitate or replicate. Managers have a responsibility to oversee resource acquisition and integration and guide the development of the routines that transform the resources. Absent an active managerial role, this process would also be reduced to luck. 
While managers' choices may be constrained by existing path dependencies, they do play a key role in resource acquisition decisions and in developing idiosyncratic routines. Managers must make decisions that maximize the likelihood of creating a valuable capability that confers a competitive advantage. We liken this to the development of an R\&D capability, which typically begins with the acquisition of scientific expertise. Over time, interactions on the research team produce a critical mass on certain types of innovations, and managers seek additional expertise that complements existing knowledge and deepens the capability. In this way, as the endeavor begins to bear fruit, the resource accumulation process might become more directed and deliberate. Despite the role of path dependencies, managers are generally active in building such a capability long before its fruits are known outside of the firm (note again that we have set aside luck-based explanations for resource acquisition).

Indeed, the distinction between the two approaches is not as stark as the debate might suggest-they are more complements than substitutes. Barney (1989) emphasized that Dierickx and Cool's (1989) asset accumulation scenario is an important source of information asymmetry in strategic factor markets. This is why he originally concluded that firms should 'look within' for sources of competitive advantage (Barney, 1986). Consider, for example, Monsanto's bold move into biotechnology. They began by establishing a venture capital firm to target investments in biotechnology startups. They followed this with acquisitions, joint ventures, alliances, and building an internal R\&D capability. Barney (1988) argued that acquisitions can be considered a form of strategic factor market. Venture capital, joint ventures, and alliances are mixtures of internal development and quasi-market mechanisms. They certainly did not acquire purely generic resources that only became specialized and valuable upon integration with the firm's other assets. Ultimately, Monsanto became a biotechnology company and spun off its core chemicals business under a separate name. As this example illustrates, while the capability was created using a mixture of internal and external transactions, managers clearly had a specific intent or foresight about what kind of company they sought to create.

\section{How much foresight do managers have?}

Of course, none of this discussion implies that managers are always right in the strategies they choose or in their assessments of what will create value. In general, managers make such decisions under great uncertainty and it is unreasonable to presume that anyone can be certain that a given strategy will produce a competitive advantage ex ante. However, it is equally unreasonable to assume that managers operate under conditions of total uncertainty and have no idea whether their strategies will be successful. This position would relegate all competitive advantage to the realm of luck since no systematic or intended strategy could yield an advantage. Indeed, one might argue that under such conditions the entire field of strategic management would have little potential to add value. Accordingly, the question of how much foresight managers actually have seems to be fairly important for the strategic management literature.

With few exceptions (Durand, 2003), there has been little research exploring how much foresight managers have and how managers might use that foresight for personal gain. ${ }^{1}$ In the case of a knowledge-based advantage, managers may own or control the primary rent-generating resources. ${ }^{2}$ Hence, managers may enjoy a strong position from which to appropriate rent (Castanias and Helfat, 1992; Coff, 1999). In contrast, shareholders generally bring the most fungible of all resources to the table. This may grant managers tremendous power in terms of their ability to influence and manage the rent distribution process. However, the extent of this power depends on the amount of managerial foresight deployed to generate the advantage.

\section{Can managers reap gains through insider trading?}

Foresight, in turn, may translate to information asymmetries. In general, the information

\footnotetext{
${ }^{1}$ The agency theory literature certainly assumes that individuals act in their own self-interest and that this may conflict with shareholder objectives. However, the agency literature addresses primarily a stable or even shrinking pie as opportunistic managers plunder the firm and send it into a spiral of declining performance. This context differs markedly from the emergence of a competitive advantage-our focus in this article.

${ }^{2}$ Professional firms rely on similar types of assets which are recognized to promote partnerships, as opposed to the corporate form in which ownership and control are separated (Milgrom and Roberts, 1992). It seems reasonable that similar issues may arise frequently from the knowledge assets at the core of a resourcebased advantage.
} 
asymmetries between investors and managers (Jensen and Meckling, 1976) tend to be amplified in the case of knowledge-based advantages because knowledge may be difficult to transfer across organizational boundaries (Kogut and Zander, 1992). Furthermore, the market has better information about a firm's physical assets than its intangible assets from which to assess the firm's prospects. One might argue that investors face a much harder task in assessing the market value of knowledge-creating firms. We need only look at the wildly fluctuating market values of biotechnology or 'dot com' firms to see the impact of complex knowledge-based assets on shareholder wealth (Lee, 2001).

Knowledge-intensive firms may therefore create settings that allow managers to exploit information asymmetries through insider trading. Note that the buying and selling of a firm's stock by managers and officers is typically routine and is rarely the focus of SEC enforcement activities. Evidence related to insider trading is consistent with managers taking advantage of the information asymmetry between insiders and outside investors (John and Lang, 1991; Karpoff and Lee, 1991; Myers and Majluf, 1984; Seyhun, 1992) In fact, Ke, Huddart, and Petroni (2003) find that insider trades are consistent with foreknowledge of future earnings, as early as 2 years prior to the earnings announcements. In R\&D-intensive firms the degree of asymmetry is amplified, which may lead to more opportunistic behavior (Coff, 2003). Furthermore, investors seem to assume that managerial trading in R\&D-intensive firms is an especially critical signal of the firms' prospects (Coff and Lee, 2003). Thus, insider trading may play an important role in the rent appropriation process. $^{3}$

\footnotetext{
${ }^{3}$ Regulation is the primary deterrent to insider trading. Managers must notify the SEC of transactions in a given month within 10 days after the end of the month. Trades are scrutinized to see if they were motivated by information about 'significant, confidential corporate developments' (Securities and Exchange Commission, 2002). In practice, enforcement focuses on trading driven by specific short-term events rather than longer-term impressions of a given strategic direction or R\&D effort. Stock prices do not reflect the implications of the insider trading until transactions become public knowledge - up to 40 days after the trade is executed. Thus, management can purchase shares at an unadjusted price and sell the shares after investors have bid up the price to reflect managers' optimism.
}

\section{Patent activity as a source of information asymmetries}

Managers have access to knowledge of important strategic events, like impending mergers or technological breakthroughs that may affect the value of the firm. Patents can be an important representation of imminent technological breakthroughs that reflect platforms upon which future innovations will be based (Ahuja and Lampert, 2001). In effect, patents reflect a capability-building process not unlike that described by Dierickx and Cool (1989). Specifically, highly cited patents are indicative of the path-dependent asset accumulation process because subsequent patents clearly build upon the initial breakthrough. Again, unless complementary assets accumulate without managerial involvement, the process relies on managerial foresight.

Furthermore, firms that want to protect their intellectual property patent vigorously and often. For example, Hewlett-Packard solidified its position in the inkjet printer market by erecting a wall of patents on their earliest breakthroughs. In this case, the initial inkjet patents reflected technologies that were inferior to the dot matrix standard. However, future patents built on (and cited) the initial technologies so that it emerged as the standard for that market segment. The early patents effectively blocked rivals from entering the inkjet market without licensing Hewlett Packard's technology. Thus, in addition to blocking rivals, patents may be valuable if they grant a firm bargaining power in licensing agreements.

The knowledge creation process begins with tacit knowledge such that the precise nature of an innovation may not be clear (Nonaka, 1994; Polanyi, 1962). At this stage, only the people directly working on the innovation may understand its full potential and even for them it may involve a gut feeling rather than any sense of certainty. At this point, knowledge of the breakthrough may not be fully accessible to senior managers or shareholders because it remains tacit or complex (e.g., embedded in a highly technical language/knowledge base).

As the knowledge process unfolds, the potential of an innovation becomes clearer and the firm begins to identify elements that may be patentable. The patent application process is long and bureaucratic. Once the firm identifies intellectual property 
it wishes to protect, it must develop an application that cites all prior innovations on which the intellectual property was based. The application requires that the underlying technology be codified and that all possible uses of the technology be specified. ${ }^{4}$ Upon submission, the application is examined carefully to see if all relevant antecedent patents are appropriately cited. The innovation must also pass the 'novelty and obviousness' tests to determine if the innovation is new and creative (Hardy, 2002).

Generally, there is a considerable period in which senior management has intimate knowledge that: (1) there has been a scientific breakthrough, (2) a patent has been applied for, and (3) the patent may be an important building block for future innovation. While a given patent may be stuck in bureaucracy for years, management may have a strong notion of its ultimate importance at the outset. The time between patent application and patent granting is referred to as the patent pending period. During the patent pending period, firms may prefer to keep knowledge of the innovation private so that rivals cannot imitate or reverse engineer the breakthrough. ${ }^{5}$ In addition, if the information about the innovation is public and/or has been used for more than a year, it no longer meets the novelty requirement for a patent. An ancillary analysis of data compiled for the present study suggested that public disclosure of breakthrough patents is relatively rare. Indeed, 68 percent of the time there was no public account of the patent at all and only 6 percent of the time did an account appear before the patent was granted.

Even once a patent is granted, investors may not know its full economic potential. First, it may take time before an innovation actually appears in the firm's products. Even then, it may take more time before the product's performance can be fully assessed in the marketplace (Ernst, 2001). Finally, if a patent is a foundation for further innovation, it may take years before subsequent patents building upon its technology are applied

\footnotetext{
${ }^{4}$ The patent office requires that 'The specification shall contain a written description of the invention, and of the manner and process of making and using it, in such full, clear, concise, and exact terms as to enable any person skilled in the art to which it pertains ... to make and use the same' (U.S. Patent Law, 1st paragraph of 35 USC $\S 112$ ).

${ }^{5}$ The American Inventors Protection Act of 1999 requires that information about pending patent applications be published, generally 18 months after an application has been filed. However, this did not apply in the period studied.
}

for and granted. The investment strategy described in our introductory quotation (at CHI research) draws on patent citation data that may take years to establish for a given patent (Barker, 2002).

Thus, senior managers may be aware of the innovation for several years from developing the technology, to preparing the patent application, to waiting for the U.S. Patent Office to grant the patent. During this period, there may be a wide information gap between investors and managers with respect to the innovation and the underlying strategic capabilities. A number of studies show that insiders can and do trade profitably on inside information (Ke et al., 2003; Seyhun, 1986). As such, it seems plausible that knowledge of technological breakthroughs would trigger insider trading.

\section{Extent and nature of managerial foresight about patent activity}

Given the information asymmetries associated with technological breakthroughs, managers may lay the groundwork for rent appropriation long before a patent has been announced. During that time, managers may trade on their foresight or private information that the firm is on the verge of a breakthrough, thereby maximizing their own wealth (Damodaran and Liu, 1993). If managers are able to recognize that a particular patent or technology has significant potential, they can personally realize a significant gain by purchasing shares early on. Thus, managers have opportunities to capitalize on their foreknowledge about technological breakthroughs before a patent has even been filed.

However, since foresight is hard to observe directly, we suggest that managers will exploit information asymmetries through insider trading when they have sufficient confidence that their foresight is accurate. Thus, patterns of insider trading should reveal the extent and nature of the managerial foresight associated with patenting breakthrough innovations. This is much like Godfrey and Hill's (1995) suggestion for dealing with such unmeasurables. Just as physicists measure vapor trails to make inferences about nuclear physics, we explore foresight by tracking observable behaviors that would result from foresight. Thus, while we are interested in the extent of managerial foresight in differentiating between innovations, we observe only the extent to which managers exploit such foresight for personal gain. If managers do not 
fully exploit their foresight, our analysis would tend to understate the actual extent of managerial foreknowledge.

\section{Foresight and patent activity as indicators of economic value}

We hypothesize that, for firms that patent, managers' trading activities are driven by their predictions of the economic impact of patent activity. However, this raises the question of what types of patent activity managers base their trading. Each year, firms manage a portfolio of innovation activities. For example, at any given time, some projects may be in early stages such that the knowledge is still tacit while others reflect codified knowledge and patents that have been applied for. We suggest that managers trade based on the progress of the overall profile of activities in a given year as well as focusing on specific breakthroughs that may occur in that time frame.

There are many ways in which the economic value of a portfolio of patent activities might be assessed. For instance, is it more important to have a flurry of small patents or one key patent that will serve as a platform for future innovations? What type of patent profile would give managers confidence in the firm's future performance?

\section{Quantity of patents}

While the number of patents is not a measure of 'breakthrough innovations,' the number of patents may be an important indicator of potential success - particularly in uncertain or fast-paced environments. Indeed, the real options literature suggests that in uncertain and dynamic environments high-performing firms invest in many different projects under the assumption that some will ultimately lack promise and will not be brought to market (McGrath, 1997). Using this logic, a large number of patents might signal that the firm is well positioned if only some of the innovations turn out to be viable in the marketplace.

Thus, the number of patents might be viewed as an indicator of a dynamic capability. Firms operating in volatile environments must continually adjust (Teece, Pisano, and Shuen, 1997). Where the dynamism is driven by rapidly changing technology, adjustments will require the ability to adapt and develop technological innovations. Furthermore, since future needs may be hard to predict, firms would need to develop and maintain different technologies and knowledge bases in anticipation that they might turn out to be useful later (Levinthal and March, 1993). This might manifest itself in the quantity of novel ideas generated and patented.

It is important to recognize that trading on the number of patents implies a relatively low level of foresight where managers cannot distinguish small innovations that tend to have little economic value from breakthroughs. They can, however, bet on a general trajectory of innovative activity and the likelihood that some projects may pan out even if it is unclear which ones will prove to be of value. Thus, even if managers lack the foresight to distinguish among innovations and identify individual breakthroughs, we might expect:

\section{Hypothesis 1: Insider purchases increase with the number of patents applied for.}

\section{Patent importance}

Managers may have stronger foreknowledge about the importance of each patent that goes beyond the sheer number of patents. Indeed, managers' trading activity may hinge more on the value of the most promising innovation in their portfolio.

There are a variety of different factors that may signal the quality or economic potential of a patent. We offer three different indicators of patent importance, including the number of citations, the number of claims, and the time or lag between when a breakthrough patent is granted and when it is cited. The first measure, the citations a patent receives in later patents, is commonly used (Trajtenberg, 1990). This measures the extent to which a given innovation serves as a platform for subsequent innovation. While this does not become apparent externally for years after a patent is granted, managers may have an idea of a patent's potential even before completing the patent application. If this knowledge guides their trades, insider purchases may serve as an early signal that the firm has a new and promising technology platform.

Breakthrough patents may be reasonably good indicators of underlying capabilities. While patents are codified, the underlying knowledge required to build on them tends to be more tacit in nature. In the case of breakthrough patents, subsequent efforts to build on the innovation were ultimately 
successful and the initial capability should be particularly valuable. Furthermore, the patent process selects novel innovations and grants firms some protection to keep the resource from rivals. In short, breakthrough patents indicate that the firm has valuable and rare resources that are unavailable to rivals - the criteria for a strategic asset (Barney, 1991).

We use two measures of patent citations to reflect breakthrough patents. The first is the number of citations received by the firm's strongest patent - the patent in the portfolio that, based on citations, has the most potential. In this way, managers may bet based on the 'speed of their fastest horse' rather than the 'number of horses they have in the race' (e.g., Hypothesis 1). Thus:

Hypothesis 2: Insider purchases increase with the number of citations received by the firm's top patent.

The second indicator is the number of breakthrough patents in a given year. First, even a firm's top patent may pale in comparison to other developments in the field-it may not represent a real breakthrough. Some patents are essentially deadends: inventions that have only a marginal value; others serve to open up significant new technological terrain. Such breakthrough patents are tremendously valuable as foundations for firms to build upon (Trajtenberg, 1990). Therefore, the number of breakthroughs compares the firm's top patents with others in the field and accounts for the possibility that a firm may have more than one breakthrough patent. To the extent that managers can identify breakthroughs early, they may be able to reap the benefits of their foresight through stock purchases. Put another way, managers may bet based on the number of really fast horses they have in the race. Accordingly:

\section{Hypothesis 3: Insider purchases increase with the number of breakthrough patents.}

Another indicator of a patent's economic value is the number of claims made about what the innovation will do. Thus, a patent on a technology that may be used in a number of ways may be more valuable than a patent that specifies a single application or use. For example, if one is patenting a chair, uses may include an object to sit on, an object to step on to reach high places, an object to display knick-knacks, etc. Applicants have an incentive to list all possible uses since this defines the scope of protection that the patent will provide.

In many cases the claims identify distinct market needs that often suggest opportunities to leverage a given innovation across markets or industries. The ability to leverage a strategic resource in this way is central to the notion of a core competence (Prahalad and Hamel, 1990). Therefore, it is not surprising that the number of uses has been linked to the commercial success of a patent (Lanjouw, Pakes, and Putnam, 1998; Lanjouw and Schankerman, 1999) and may be one indicator that managers respond to in assessing a patent's impact on firm performance. Thus:

\section{Hypothesis 4: Insider purchases increase with the number of claims associated with the firm's top patent.}

A final way to test the nature of managerial foresight is the extent to which trading is driven by subsequent work that builds upon a patent. Our previous hypotheses addressed this through measures of citation impact. However, citation impact does not measure the speed with which a patent is cited. Some patents have a more immediate impact. Their arrival quickly spurs follow-up work. For other patents, their importance may become visible only after a significant lag.

Other things being equal, managers may be more adept at identifying patents when the impact is imminent. This is particularly true in the context of causal ambiguity where subsequent innovations may be harder to identify and predict (Mosakowski, 1997; Reed and DeFillippi, 1990). Further, managers may prefer to bet on technologies that are likely to yield immediate fruit given the inherent uncertainty of the technology arena. Accordingly, the shorter the lag before a patent is cited, the more managers are likely to purchase shares. Thus:

Hypothesis 5: Insider purchases decrease as the length of time before the firm's top patent is cited increases.

\section{Timing of foresight}

The above hypotheses focus on different aspects of patent activity. We now turn to the timing of managerial foresight: when do managers act on 
their perceptions that patent activity will create value? Again, since foresight cannot be easily observed, we focus on the point at which managers are sufficiently confident in the accuracy of their foreknowledge that they use it in making personal investment decisions. Since managers are aware of patents before the actual filing and granting, and investors may not know the economic impact until well after the patent has been granted, the period in which managers may purchase shares in their firm is quite long. We can divide up the time period into three 'windows' in which to test for trading activity: the year before patents are applied for $(t-1)$, the year in which patent applications are filed $(t)$, and the year after patents have been applied for $(t+1)$. There is little reason to focus on later periods because after the patent is granted much of the relevant information about the innovation should be public knowledge and the opportunity to profit from information asymmetries will have waned.

In each case, there would generally be information asymmetries that managers could exploit. However, if managers have strong foresight, the opportunities to profit may be greater in the first period when managers are developing a patent application. This is the time period in which the full potential of an innovation should first be revealed to top managers since efforts are under way to codify the knowledge and it should be more fully understood. Put another way, there is less new knowledge being revealed to top managers in the later periods since much of the information about the innovation is already codified, even though such information may remain unavailable to investors. Furthermore, the details of the innovation may be released over time to the public, reducing opportunities to profit in later periods. We therefore predict that top managers will be most likely to trade in the year before patent applications are filed $(t-1)$. Thus:

Hypothesis 6a: Insider purchases will increase with patent activity in the year before a patent is applied for (e.g., year $t-1)$.

There are several alternatives to this hypothesis since information asymmetries with investors persist well beyond this point. However, these would suggest lower levels of foresight since managers would apparently lack sufficient confidence in their foreknowledge to use it to seek personal gain in earlier periods. For example, it may be that top managers only become aware of the true importance of patents at the time that patent applications are filed (e.g., a lag as the information travels in the management hierarchy). This implies that top managers are out of the loop or otherwise uninvolved in R\&D investment decisions and technology development until its fruits are quite apparent.

While one might expect managers to understand the importance of an innovation once much of the knowledge is codified, it is possible that followon innovations and early market signals coincide more with the later periods (e.g., the period when the patent is pending but has not yet been granted). For example, it may be that top management enthusiasm peaks when subsequent innovations are developed and/or they have results from early market tests of the innovation. In this case, top managers may be more likely to trade on their private knowledge when the patent application is filed or even after the application is under review. Therefore, we present the following alternative hypotheses:

Hypothesis 6b: Insider purchases will increase with patent activity in the year that a patent is applied for (e.g., year $t)$.

Hypothesis 6c: Insider purchases will increase with patent activity in the year after a patent is applied for (e.g., year $t+1$ ).

\section{DATA AND METHODOLOGY}

\section{Sample and data}

The sample includes all firms that (1) are publicly traded and (2) received approval for at least one patent that was applied for between 1988 and $1990 .^{6}$ Insider trading data are available for firms that are publicly traded and we are only interested in those firms that sought patent protection for innovations (in order to assess whether the quality or quantity of patents affects trading activity). Data on 285,465 patents were originally taken from the U.S. Patent Office (USPTO) and initially cleaned

\footnotetext{
${ }^{6}$ These years have been chosen because we need information on subsequent patent importance, a measure that requires a substantial follow-up period.
} 
by Hall and others (Hall, Jaffe, and Trajtenberg, 2001). Because the USPTO does not accurately attribute patents to firms using unique identifiers, it is necessary to link the patents to the firms manually. For example, patents for IBM might be entered as 'IBM Corp.,' 'IBM, Inc.,' or 'International Business Machines,' among other possible names. These linkages have been clarified for large COMPUSTAT firms. We augmented this by coding the data for smaller publicly traded firms. In this way, our sample better represents actual patent activity. Of the 285,465 patents, 101,963 were identified as attributable to 3300 firms that were publicly traded at some point. However, not all of the firms were publicly traded during the period studied and many could not be matched to other data sources. Ultimately, the sample included 1269 firms that were matched with COMPUSTAT, CRSP, and Thompson Financial's insider trading database.

Our analysis is based on patents that were applied for and ultimately granted because, during the period studied, there was no information available publicly on failed applications. This same limitation applies to nearly all research that draws on U.S. patent data. Published statistics suggest that approximately 75 percent of all patent applications are ultimately granted (U.S. Patent and Trademark Office, 2002). However, sources at the USPTO indicated that, for our sample, the success rate is probably quite close to 100 percent because: (1) organizations have higher patent granting rates than individuals; (2) domestic applicants have higher patent granting rates than foreign applicants; and (3) corporations often refile or amend patents even if an initial attempt fails (U.S. Patent and Trademark Office, 2003). To verify this, we explored some key corporate success rates during the period after 2001 when patent applications were made public. Of the patents applied for in January of 2001, Intel, Toshiba, GE, and Kodak had 100 percent of their patents granted 24 months later. In the same period, IBM had 83 percent, Xerox had 71 percent, Motorola had 66 percent, and 3M had 61 percent granted. These rates would be higher if calculated over a longer period since 24 months is the average patent pending period and many take considerably longer. As such, we do not anticipate that the restriction to patents that have ultimately been granted introduces any systematic bias.

\section{Time periods}

Our hypotheses involve testing the impact of patent applications in several periods. We began by identifying the 'top' patent for each firm during the 3-year time frame studied using the patent performance measures described earlier. ${ }^{7}$ We defined a firm's 'top' patent as that which was mostly heavily cited, had the most claims, and for which subsequent work was under way soonest (e.g., patent was cited quickly). Using these criteria, there was a single patent that appeared strongest for nearly all the firms. For the few firms (14) that had multiple top patents, we selected the earlier patent but tested whether these observations influenced the results. Of course, we also control for this by using the number of breakthrough patents to test Hypothesis 3.

Once a top patent was identified for each firm, the time periods were constructed around the patent application dates. The first and earliest period ran from 18 months before the application date to 6 months before the application date. The second period represented the year in which the patent application was filed (6 months before and after the application date). Finally, the third and latest period ran from 6 months after the patent was filed to 18 months after the patent was filed. A relatively high degree of foresight would exist if managers trade on knowledge of top patents in the first period (before the application is filed) - especially when compared to trading in the third period when the patent has been pending for some time.

\section{Dependent variable}

Our dependent variable is the natural $\log$ of the value of shares purchased on the open market by all insiders (Stock purchases) in a given year. Specifically, this is the number of shares purchased multiplied by the average purchase price for all insider purchases in a given year. Following Seyhun (1990), we set aside other transactions such

\footnotetext{
${ }^{7}$ We selected each firm's top patent because we wished to test whether managers viewed it as an important event as evidenced by their trading patterns. However, there remains a great deal of variation in patent quality - not every firm generates breakthroughs. Indeed, most patents are mundane and their economic value is somewhat suspect. The range of top patents for firms in the sample is quite wide: citations received ranges from 1 to 311 ; claims ranges from 1 to 868 ; and the forward lag ranges from 0 to 10 years.
} 
as the exercise of options and shares acquired from compensation plans, since the timing and amount of these transactions may not reflect management's private information so much as the structure of the compensation system. Insider trading data come from Thompson Financial Corporation's database, which covers all insider trading activity reported to the SEC: 187,018 insider trading events in 11,174 firms between 1985 and 1992. Information about these trades is released in bundles as they are reported to the SEC monthly. Thus, an event may include several trades from a given manager along with trades from other managers. The dollar value of the shares purchased is log-transformed because of the skewed nature of the variable especially when comparing large and small firms.

\section{Independent variables}

We use several independent variables drawn from the patent data to measure the quality and quantity of patent activity in a given year. First, we use the number of patents (\#Patents) applied for to test whether the number of patents in a given year influences insider trading (Hypothesis 1).

Patent citations received (Cites received) refers to the number of times a patent was cited in subsequent patents. This measure was described in our introductory quote as the basis for CHI research's investment fund (Barker, 2002). We used citations to the patent through 1999. Our sample focuses on the late 1980s and early 1990s to allow time to calculate citations for patents studied. In general, the more citations a patent receives, the greater the economic value (Harhoff et al., 1999; Narin, Carpenter, and Woolf, 1984; Trajtenberg, 1990). Cites received is a count of the number of citations received by the most heavily cited patent over the 3-year period. In other words, it measures the strength of a firm's best patent. This variable is adjusted by the average citations for a patent in that technology subfield. NBER scholars have classified patents into 36 technology subfields and we use their classification here (Hall et al., 2001). In this way, we control for patents in technologies where the citation norms may differ. This is similar to different citation practices in different academic fields. Cites received was used to test Hypothesis 2.

From this, we created another variable - number of breakthrough patents - which identifies the number of patents a firm applied for that were ultimately in the top 10 percent most heavily cited in their technology subfield (\#Breakthroughs). This variable was used to test Hypothesis 3: trading driven by the number of breakthrough patents. This variable, based on Ahuja and Lampert (2001) and calculated from Cites received, allows us to recognize when firms have multiple breakthroughs in the same year. We experimented with several possible cut-off points between 10 percent and 0.5 percent. However, since these were highly correlated and the results were not sensitive to the cut-off point, we only present the 10 percent cutoff point here. The two variables Cites received and \#Breakthroughs were never included in the same model because one is used to calculate the other.

We also tested the impact of patent value based on the number of claims (Claims) made for each patent (a test of Hypothesis 4). This reflects the number of distinct uses specified for the innovation in the patent. It is in a firm's best interest to fully specify how the innovation is to be applied so that they have complete coverage for all of the applications they intend to exploit. As such, this is a useful proxy for how many applications a given innovation may have. Like Cites received, the average claims made for the patent's technology subcategory was subtracted to account for different norms for claims by type of technology.

Finally, we explored the extent that trading was driven by the speed with which follow-on work was under way using the lag before a patent was cited (Cite lag). This variable, used to test Hypothesis 5, reflects the citation lag (in years) for the firm's strongest patent. The general idea is that managers may have less foresight about patents when there is a long lag before subsequent work recognizes the initial patent.

\section{Control variables}

Five control variables were drawn from the Center for Research on Securities Prices (CRSP), Thompson Financial's Insider Trading database, and COMPUSTAT. First, we control for shares that insiders held and sold during the time periods. Insider holdings (Holdings) are important because they suggest how much stock the insiders already have in their portfolio. In general, when managers have large holdings, one would not expect them to 
purchase much additional stock on the open market. In that context, they might prefer to diversify their holdings into other investments. If a manager already has very significant holdings, he or she may be less prone to buying additional shares in response to positive events or private knowledge $^{8}$ Similarly, a stock purchase may be especially meaningful if managers already have strong holdings. This variable was normalized by the total shares outstanding to account for very large firms where managers may hold a very small portion of the shares. This is also log-transformed because of the skewed nature of the variable's distribution.

Similarly, shares sold (Shares sold) indicates how many shares insiders sold during each period. Managers sell shares far more often than they initiate open market purchases. This is, in large part, due to firms' tendencies to provide stock-based compensation. If managers wish to use their compensation for personal consumption, they must sell shares. This may not always reflect a strong negative signal to the marketplace since the sales may have little to do with the firm's prospects. However, open market purchases are almost certainly strong positive signals about the firm. Clearly, if managers are selling stock during a given period, this would suggest that they see less need to buy more stock. By controlling for this, we keep the focus on open market purchases, which have great meaning for investors, but, algebraically, this is similar to using net purchases as the dependent variable.

Two control variables - Spread and the Marketto-book ratio - indicate when there may especially be opportunities to profit from movement in the stock price. The spread serves as a proxy for stock volatility and refers to the gap between the highest and lowest prices that the stock reached in the year (Spread). Other things being equal, the larger the spread, the greater is the opportunity to profit from the stock. We therefore anticipate a positive relationship between the spread and insider stock purchases. The market-to-book ratio (Market to book) has been used as a proxy for Tobin's $q$, which is intended to measure how well the firm's assets are deployed. A high value might indicate that the market has valued important intangible assets not

\footnotetext{
${ }^{8}$ This suggests the possibility that holdings might interact with our other measures as opposed to having a main effect. We did test this possibility and found no significant interactions. However, as we present below, this control variable had a very strong main effect in predicting stock purchases.

reflected in the book value. As such, we anticipate that a high value might mean that information about imminent breakthroughs is already incorporated in the stock price and there are fewer opportunities to profit from additional upward movement. In other words, a higher market-to-book ratio might be associated with fewer insider stock purchases because it implies that some of the information about patent quantity and quality has already been leaked to the market. On the other hand, a high market-to-book ratio may indicate that both managers and investors are optimistic about the firm's prospects - suggesting enhanced insider purchases.

We also controlled for the natural logarithm of the firm's revenue (Sales) to reflect firm size. Big companies have larger top management teams and higher compensation. Therefore, we would anticipate that the amount of insider purchases for the top management team would be greater for large firms. We also initially included a number of other financial controls from COMPUSTAT (change in sales, assets, operating income, etc.). However, the variance explained by these was absorbed by the controls that directly measured movement in the stock price itself. Ultimately, since these accounting-based measures did not substantively affect our results, they are not shown here.

\section{Analysis}

While these data span several years, each model included only one observation per firm. That is, we constructed time periods around the filing of each firm's top patent. We then examined how that patent activity affected trading before the application was filed, in the year it was filed, and after it had been pending for some time. Since this was not panel data, analyses were conducted with lagged variables but time series data analysis was not required.

As a robustness check, we conducted an analysis based on patent activity in each of the three calendar years studied (1988-90). Specifically, we examined a firm's portfolio of patents in a given year, based on the number of patents, the number of highly cited patents, and the number of claims made with each patent. This has the advantage of allowing for multiple observations per firm and increasing the statistical power. However, this is not ideal because the patent activity is not aligned with the time periods. For example, the firm's top 
patent in a given year might be filed in January or December - up to 12 months apart. Since we are interested in when managers act on their foresight, this added imprecision in the timing of the event might create considerable noise. Nevertheless, this analysis yielded comparable results in both fixed and random effects time series models. Despite this, we concluded that it was more important to use carefully aligned time periods based on the firms' top patents in order to draw inferences about the timing of managerial foresight (Hypothesis 6).

\section{RESULTS}

Table 1 shows descriptive statistics for the sample. Our dependent variable, the value of shares purchased (Stock purchases), is significantly correlated with all of the other variables. It is most strongly correlated with Shares sold (0.32), Spread (0.36), and Sales (0.27). These carry the signs we had anticipated earlier. For example, the greater the Spread between the high and low prices in the year, the greater the opportunity to profit may be and the more shares we would expect managers to purchase. In addition to this, as we have suggested, all of the variables summarizing patent activity are positively correlated with the shares purchased except Cite lag, which is hypothesized to have a negative effect.

There are also significant correlations among other variables. The patent variables have correlations ranging from -0.16 to 0.58 . For example, the number of citations the best patent received (Cites received) and the number of breakthrough patents (\#Breakthroughs) have a significant correlation of 0.47 . This is not surprising since the variable \#Breakthroughs has been created from the number of citations received. Cites received is also significantly correlated with \#Patents (0.53). Presumably, an increase in the number of patents should be related to an increase in highly cited patents as well.

Collinearity among these variables is not anticipated to be a problem because the highest correlated variables in the same model-Cites received and \#Patents - are correlated at 0.53. The other correlations, while significant, are not so strong as to raise concerns about multicollinearity. Furthermore, the highest variance inflation factor was 2.4 and the average inflation factor was 1.33 . Chatterjee and Price (1991) suggest that multicollinearity is problematic when the highest variance inflation factor exceeds 10 and/or the average variance inflation factor is considerably larger than 1 .

\section{Timing of foresight}

Table 2 presents results of our regression analysis with insider purchases as the dependent variable and measures of patent quantity and quality as independent variables of interest. The different models test the timing of managerial foresight suggested in Hypothesis 6. We present two models in each time period because \#Breakthroughs is closely related to \#Patents and Cites received and they should not be presented in the same model. While they are conceptually distinct and the correlations are not unreasonably high, \#Breakthroughs is a subset of the \#Patents in that both are count variables based on patent activity. Similarly, while Cites received is the citations of the most highly cited patent, \#Breakthroughs is a count only of the most highly cited patents. Thus, Models A and B test whether managers purchase shares based on patents to be applied for in the following year (Hypothesis 6a). Models C and D test whether managers purchase shares based on patents applied for in the current year (Hypothesis 6b). Finally Models $\mathrm{E}$ and $\mathrm{F}$ test whether managers purchase shares based on patents that were applied for in the previous year (Hypothesis 6c). In this way, each hypothesis about the nature of foresight is tested for each time period in which foresight might occur.

All of the models are significant, with $F$ statistics between 20.85 and $77.40(p<0.001)$. Most of the control variables are significant in the anticipated directions. For example, Shares sold is negatively associated with insider purchases, while the Spread and Sales are linked to more insider purchasing.

Nearly all of the independent variables (Claims, Cites received, Cite lag, \#Breakthroughs) are significantly related to insider purchases in the year prior to patent filing in the predicted directions (Models A and B). Thus, four out of five tests provide support for Hypothesis 6a. The fifth variable, \#Patents, was significant in the middle period (Model D), suggesting that managers trade on the number of patents later and specific individual breakthroughs earlier. This is the only evidence 


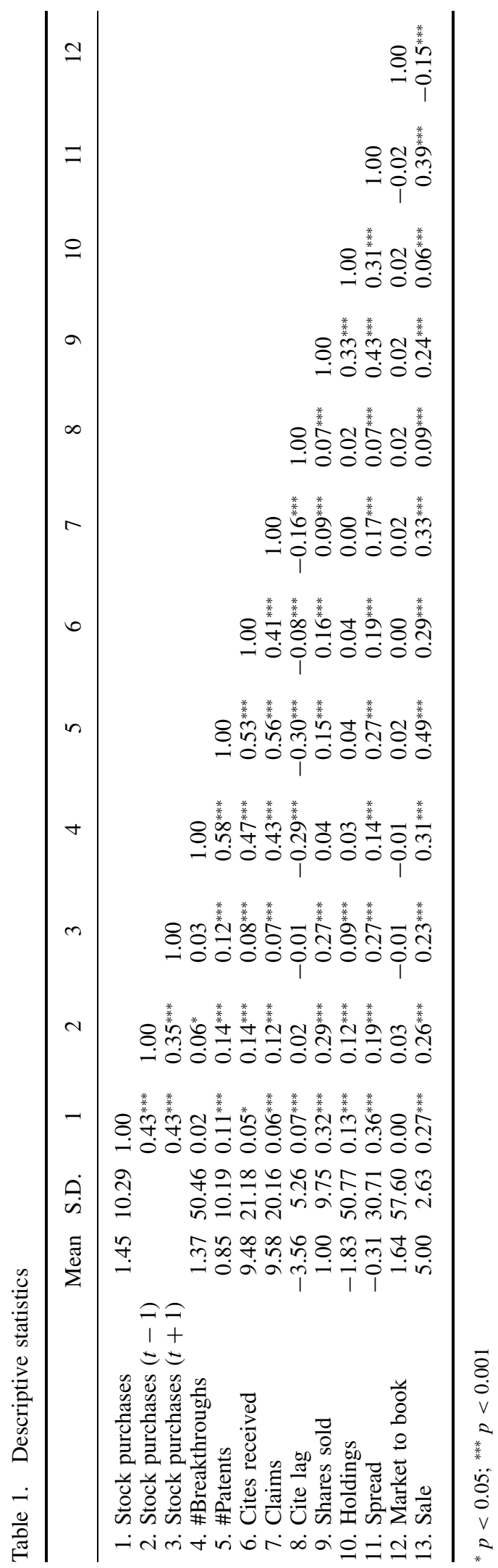


Table 2. Regressions predicting insider stock purchases

\begin{tabular}{|c|c|c|c|c|c|c|}
\hline \multirow[t]{2}{*}{ Variables } & \multicolumn{2}{|c|}{$\begin{array}{l}\text { Purchases before patents } \\
\quad \text { filed }(t-1)\end{array}$} & \multicolumn{2}{|c|}{$\begin{array}{l}\text { Purchases as patents } \\
\text { filed }(t)\end{array}$} & \multicolumn{2}{|c|}{$\begin{array}{l}\text { Purchases after patents } \\
\text { filed }(t+1)\end{array}$} \\
\hline & $\begin{array}{c}\text { A } \\
\text { \#Breakthroughs }\end{array}$ & $\begin{array}{c}\mathrm{B} \\
\text { Cites/\#Patents }\end{array}$ & $\begin{array}{c}\text { C } \\
\text { \#Breakthroughs }\end{array}$ & $\begin{array}{c}\mathrm{D} \\
\text { Cites/\#Patents }\end{array}$ & $\frac{\mathrm{E}}{\text { \#Breakthroughs }}$ & $\begin{array}{c}\mathrm{F} \\
\text { Cites/\#Patents }\end{array}$ \\
\hline \#Breakthroughs & $\begin{array}{l}0.07^{* *} \\
(0.03)\end{array}$ & & $\begin{array}{c}0.05 \\
(0.06)\end{array}$ & & $\begin{array}{c}0.02 \\
(0.05)\end{array}$ & \\
\hline \#Patents & & $\begin{array}{c}-0.20 \\
(0.25)\end{array}$ & & $\begin{array}{l}0.78^{* *} \\
(0.30)\end{array}$ & & $\begin{array}{l}0.23 \\
(0.371)\end{array}$ \\
\hline Cites received & & $\begin{array}{l}0.02^{* *} \\
(0.01)\end{array}$ & & $\begin{array}{c}-0.02 \\
(0.02)\end{array}$ & & $\begin{array}{c}0.01 \\
(0.02)\end{array}$ \\
\hline Claims & $\begin{array}{l}0.03^{* *} \\
(0.01)\end{array}$ & $\begin{array}{l}0.03^{* *} \\
(0.01)\end{array}$ & $\begin{array}{c}-0.02 \\
(0.02)\end{array}$ & $\begin{array}{c}-0.02 \\
(0.02)\end{array}$ & $\begin{array}{c}0.02^{\dagger} \\
(0.02)\end{array}$ & $\begin{array}{c}0.01 \\
(0.02)\end{array}$ \\
\hline Cite lag & $\begin{array}{c}-0.24^{* * *} \\
(0.08)\end{array}$ & $\begin{array}{c}-0.25^{* * *} \\
(0.08)\end{array}$ & $\begin{array}{c}0.15 \\
(0.13)\end{array}$ & $\begin{array}{c}0.15 \\
(0.13)\end{array}$ & $\begin{array}{c}0.08 \\
(0.13)\end{array}$ & $\begin{array}{c}0.09 \\
(0.13)\end{array}$ \\
\hline Controls & & & & & & \\
\hline Shares sold & $\begin{array}{r}-0.07^{*} \\
(0.03)\end{array}$ & $\begin{array}{r}-0.07^{*} \\
(0.03)\end{array}$ & $\begin{array}{c}-0.11^{* * *} \\
(0.03)\end{array}$ & $\begin{array}{c}-0.11^{* * *} \\
(0.03)\end{array}$ & $\begin{array}{c}-0.12^{* * *} \\
(0.03)\end{array}$ & $\begin{array}{c}-0.12^{* * *} \\
(0.03)\end{array}$ \\
\hline Holdings & $\begin{array}{l}0.14^{* *} \\
(0.05)\end{array}$ & $\begin{array}{l}0.13^{* *} \\
(0.05)\end{array}$ & $\begin{array}{l}0.16^{* * *} \\
(0.05)\end{array}$ & $\begin{array}{l}0.17^{* * *} \\
(0.05)\end{array}$ & $\begin{array}{c}0.13^{*} \\
(0.06)\end{array}$ & $\begin{array}{l}0.15^{* *} \\
(0.06)\end{array}$ \\
\hline Spread & $\begin{array}{l}0.96^{* * *} \\
(0.09)\end{array}$ & $\begin{array}{l}0.97^{* * *} \\
(0.08)\end{array}$ & $\begin{array}{l}0.95^{* * *} \\
(0.08)\end{array}$ & $\begin{array}{l}0.94^{* * *} \\
(0.08)\end{array}$ & $\begin{array}{l}0.88^{* * *} \\
(0.10)\end{array}$ & $\begin{array}{l}0.85^{* * *} \\
(0.10)\end{array}$ \\
\hline Market to book & $\begin{array}{l}13.10 \\
(8.50)\end{array}$ & $\begin{array}{l}13.30 \\
(8.55)\end{array}$ & $\begin{array}{l}0.75^{* * *} \\
(0.19)\end{array}$ & $\begin{array}{l}0.71^{* * *} \\
(0.19)\end{array}$ & $\begin{array}{c}0.17^{*} \\
(0.08)\end{array}$ & $\begin{array}{l}0.16^{*} \\
(0.08)\end{array}$ \\
\hline Sales & $\begin{array}{l}0.73^{* * *} \\
(0.12)\end{array}$ & $\begin{array}{l}0.78^{* * *} \\
(0.13)\end{array}$ & $\begin{array}{l}0.42^{* * *} \\
(0.13)\end{array}$ & $\begin{array}{l}0.42^{* *} \\
(0.13)\end{array}$ & $\begin{array}{l}0.69^{* * *} \\
(0.14)\end{array}$ & $\begin{array}{l}0.69^{* * *} \\
(0.14)\end{array}$ \\
\hline$N$ & 1269 & 1269 & 1255 & 1255 & 1204 & 1204 \\
\hline$F$ & $77.40^{* * *}$ & $57.11^{* * *}$ & $28.17^{* * *}$ & $26.45^{* * *}$ & $23.92^{* * *}$ & $20.85^{* * *}$ \\
\hline$R^{2}$ & 0.24 & 0.25 & 0.15 & 0.16 & 0.16 & 0.16 \\
\hline
\end{tabular}

${ }^{\text {a }}$ Standard errors are shown in parentheses. Significance tests are one-sided for hypothesized effects.

$\dagger p<0.1 ;{ }^{*} p<0.05$; $^{* *} p<0.01$; ${ }^{* * *} p<0.001$

in support of Hypothesis 6b. Claims is marginally significant in the year after patents are filed (Model E) but the effect is stronger in the earlier period (Model B). In sum, while there is some weak support for Hypotheses $6 \mathrm{~b}$ and $6 \mathrm{c}$, the strongest and most consistent support is for Hypothesis 6a, that managers have relatively strong foresight and trade on breakthroughs before they have even applied for the patents. This is not surprising since the information asymmetry between investors and managers should be greatest when assembling a patent application. This is the point at which knowledge is often first codified and the implications become apparent to managers but the information is still unavailable to investors.

\section{Patent quantity and quality}

Given that managers appear to act on their foresight in the year before applying for a patent (Models A and B), the other hypotheses focus on the extent and nature of this foresight. Models A and B test the five indicators of patent quality (e.g., \#Breakthroughs, Claims, Cite lag, \#Patents, and Cites received) before applying for a patent ( -6 months to -18 months). Interestingly all were significant in the predicted directions except \#Patents. Thus, insider purchases increase with the number of citations received, the claims made, and the number of breakthroughs. Accordingly Hypotheses 2-4 are supported. In addition, insider purchases decrease when there is a longer lag before citations appear (Cite lag), suggesting support for Hypothesis 5. While all of these are significant, the support is perhaps strongest $(p<0.001)$ for Hypothesis 5, which suggests that insider purchases are driven by follow-on work under way to develop innovations that build on the patent (Cite lag). Again, managers seem to anticipate innovations well before the patents are applied for but this foresight may be augmented by the extent of related work in progress. 
\#Patents was significant only in the year that patents were applied for, providing support for a relatively weaker level of managerial foresight. That is, where managers can identify a major innovation, they trade on that knowledge well before a patent has even been applied for. However, with smaller innovations, they are likely to trade as patent applications are assembled and filed. Recalling that Hypothesis 1 tests for lower levels of foresight and was motivated by arguments, such as real options that imply great uncertainty, it is not surprising that this is supported in a later period.

Thus, it appears that managers are able to distinguish between minor patents and those that form the bases for a great deal of follow-on work. However, to some extent they also appear to be applying a real options approach-basing trades on the number of $R \& D$ options the firm holds rather than which ones hold the most promise.

\section{DISCUSSION AND IMPLICATIONS}

Most of the theory building and empirical effort in the strategic management literature has focused on factors that might lead to a competitive advantage. However, the existing literature has not explored the extent of managerial foresight associated with these theories or ways in which managers may exploit their foresight for personal gain. Furthermore, the broader question of who will reap the gains from a competitive advantage is relatively unexplored (Barney, 2001). This study identifies managerial foresight as a critical element of the resource-based view, and explores its extent and impact.

Our results suggest that managers do anticipate breakthrough innovations and trade on that information before patent applications have been filed. Moreover, this trading activity is more sensitive to the quality of the most promising patents than to the volume of patenting activity. Thus, it would appear that trading patterns reflect an attempt to anticipate which patents will confer an advantage to the firm.

\section{Is insider trading equivalent to rent appropriation?}

We have not measured the extent to which managers enhanced their wealth directly in this study.
It is therefore reasonable to ask how insider purchasing is related to rent appropriation. Our evidence suggests that managers are trading based on accurate information much of the time (e.g., they appear to identify breakthroughs ex ante). While we do not test it here, there is ample evidence that investors respond favorably to open market purchases by insiders (Damodaran and Liu, 1993; Seyhun, 1992). This effect is even stronger in R\&D-intensive settings (Coff and Lee, 2003). Managers may sell their shares shortly after markets have adjusted upward to reflect the information conveyed by their purchases. Alternatively, they may wait until the innovation is widely understood and fully reflected in the firm's share price. While we do not measure exactly when managers divest, they would profit in either case, assuming their private information is accurate-something that seems reasonably evident from our analysis.

Thus, such trading might be considered as a form of pre-emptive rent appropriation. This observation raises a number of questions that warrant further inquiry and discussion. First, does this type of insider trading hurt investors? Second, what are other implications of the information asymmetries embedded in the resource-based view? Third, how and when is rent from a competitive advantage appropriated? Finally, what are the implications for identifying and measuring competitive advantages? We explore these questions below.

\section{Are shareholders injured?}

Given that insider trading may be a form of rent appropriation, it is natural to ask from whom insiders are appropriating the rent. Let us suppose that a firm's stock is trading at a price of $P_{0}$ when managers purchase shares based on knowledge of an imminent breakthrough. The public announcement and commercialization of the breakthrough may be years away, but managers are confident from initial indications. We assume that the share price will increase to $P_{2}$ when the full extent of the breakthrough becomes publicly known. Upon announcement of managers' trades, other investors purchase shares-driving up the price to $P_{1}$, where $P_{0}<P_{1}<P_{2}$, since detailed information about the breakthrough remains undisclosed. Eventually, the firm announces details of the breakthrough-pushing the price from $P_{1}$ to $P_{2}$. Thus, managerial trading releases information 
(e.g., that managers are confident) earlier than would have otherwise been the case.

Those who owned a stake before the insider purchases benefit as their shares increase in value sooner than would have otherwise been the case. Investors who buy after management has traded realize lower gains than if management had not traded. They do not benefit when the stock price moves from $P_{0}$ to $P_{1}$ since they did not initially hold shares. If such investors would have bought even without observing insider's purchases, this is a loss attributable to the insider trading. In contrast, if they were attracted by management's signal of confidence, they would not have received any gains (e.g., they receive $P_{2}-P_{1}$ by following management's lead).

A relatively small number of investors might be worse off for unknowingly selling shares to insiders and missing out on gains from selling later. However, this group of investors would have given up voting rights by selling shares and many of them may no longer hold shares at all. Thus, continuing shareholders would have little incentive to curtail insider trading.

Accordingly, such rent appropriation may not be deleterious for most shareholders. Most shareholders benefit from the signals provided through insider trading as some reap gains sooner, while others gain by following management's lead. In addition, shareholders may benefit if managers guard strategic information so it doesn't fall into rivals' hands. We believe that this somewhat controversial issue warrants further theory development and empirical study.

\section{Competitive advantage and information asymmetries}

The resource-based view focuses on unique resources under the firms' control that confer a sustainable advantage (Barney, 1991). However, the factors that keep strategic resources from rivals suggest that, more often than not, the key resources will be knowledge-based. Indeed, a dependence on tacit knowledge may keep the advantage from being imitated or acquired by competing firms (Reed and DeFillippi, 1990).

This suggests that information asymmetries are fundamental to the resource-based view. Researchers have been most interested in the end product-resource asymmetries across firms that generate performance differences. However, to sustain these differentials, information asymmetries must persist and keep strategic resources from rivals. As a result, information asymmetries proliferate within the firm, especially between managers and shareholders.

Agency theory has focused largely on how individuals might take advantage of information asymmetries. This article has presented one way in which managers might use their information advantage to profit personally. In so doing, we have linked the strategic importance of knowledge creation with problems addressed in the agency theory literature. These literatures have been largely separate and the agency problems created by such assets have not been fully addressed in the strategy literature. Indeed, the focus has been almost entirely on the strategic benefits that firms (and stockholders) may gain through knowledge creation rather than opportunism-based dilemmas that may result (Barney, 1991; Conner and Prahalad, 1996).

This study explores whether managers are able to take advantage of these information asymmetries. As discussed above, this may not represent a conflict of interests with shareholders. However, it raises a whole spectrum of agency-oriented problems that may be embedded in the resourcebased view. Indeed, the real question is whether there are other more subtle ways that stakeholders can take advantage of these information asymmetries. The attributes of knowledge-based assets may also pave the way for a variety of agency problems that are unrelated to capital markets (motivation, hiring, etc.). Clearly, proponents of the knowledge-based theory of the firm should consider the dilemmas that knowledge-based assets pose along with their benefits. Further research should explicitly link knowledge-based assets to the threat of opportunism and explore how managers might use their information advantages to advance their own interests.

\section{Measuring rent generation}

A second domain of inquiry strikes at the core question in the strategic management literature: why do some firms outperform others (Rumelt et al., 1991). To address this, we must have an understanding of how to measure rent that is generated, independent of which stakeholders in the firm might appropriate the rent. For example, managers may appropriate rent in a variety of ways 
including unusually high compensation (e.g., in excess of the minimum amount required to hold them in place). Our results suggest that managers may appropriate rent in the form of insider trades. Accounting-based performance measures necessarily treat payments to managers as expenses and exclude any rent they may appropriate from measures of profitability (Coff, 1999). To the extent that market-based performance measures respond to accounting performance, these may also exclude rent appropriated by insiders.

These issues are particularly pertinent when corporate governance structures are under review and changing. With the fall of prominent firms such as Enron and WorldCom, corporate governance and rent appropriation issues have taken center stage among institutional investors, the SEC, and the U.S government. It is important to point out that our results do not suggest further governmental intervention with regard to insider trading. Rather, our study merely hints at the myriad of research questions that have yet to be answered.

\section{ACKNOWLEDGEMENTS}

We thank Bob Drazin, Don Hatfield, Michael Leiblein, and Sunil Wahal for helpful comments along with those of seminar participants at the University of Texas-Austin, Arizona State University, Hong Kong University of Science and Technology, and the University of California at Irvine. We also appreciate the able data assistance of Lan Wang, Linzie Steinbach, and Ashley Steinbach.

\section{REFERENCES}

Ahuja G, Lampert CM. 2001. Entrepreneurship in the large corporation: a longitudinal study of how established firms create breakthrough inventions. Strategic Management Journal, Special Issue 22(6-7): 521-543.

Amit R, Schoemaker PJH. 1993. Strategic assets and organizational rent. Strategic Management Journal 14(1): 33-46.

Barker R. 2002. Tech stocks: follow the patents? BusinessWeek 11 March(3773): 98.

Barney JB. 1986. Strategic factor markets: expectations, luck, and business strategy. Management Science 32(10): 1231-1241.

Barney JB. 1988. Returns to bidding firms in mergers and acquisitions: reconsidering the relatedness hypothesis. Strategic Management Journal, Summer Special Issue 9: $71-78$.
Barney JB. 1989. Asset stocks and sustained competitive advantage: a comment. Management Science 35(12): 1511-1513.

Barney JB. 1991. Firm resources and sustained competitive advantage. Journal of Management 17(1): 99-120.

Barney JB. 2001. Is the resource-based 'view' a useful perspective for strategic management research? Yes. Academy of Management Review 26(1): 41-56.

Castanias RP, Helfat CE. 1992. Managerial and windfall rents in the market for corporate control. Journal of Economic Behavior and Organization 18(2): $153-184$.

Chatterjee S, Price B. 1991. Regression Analysis by Example (2nd edn). Wiley: New York.

Coff RW. 1999. When competitive advantage doesn't lead to performance: the resource-based view and stakeholder bargaining power. Organization Science 10(2): 119-133.

Coff RW. 2003. Bidding wars over R\&D intensive firms: knowledge, opportunism and the market for corporate control. Academy of Management Journal 46(1): 74-85.

Coff RW, Lee PM. 2003. Insider trading as a vehicle to appropriate rent from R\&D. Strategic Management Journal 24(2): 183-190.

Conner KR, Prahalad CK. 1996. A resource-based theory of the firm: knowledge versus opportunism. Organization Science 7(5): 477-501.

Damodaran A, Liu CH. 1993. Insider trading as a signal of private information. Review of Financial Studies 6(1): 79-119.

Dierickx I, Cool K. 1989. Asset stock accumulation and sustainability of competitive advantage. Management Science 35(12): 1504-1511.

Durand R. 2003. Predicting a firm's forecasting ability: the roles of organizational illusion of control and organizational attention. Strategic Management Journal 24(9): 821-838.

Ernst H. 2001. Patent applications and subsequent changes of performance: evidence from time-series cross-section analyses on the firm level. Research Policy 30(1): 143-157.

Godfrey PC, Hill CWL. 1995. The problem of unobservables in strategic management research. Strategic Management Journal 16(7): 519-533.

Hall BH, Jaffe A, Trajtenberg M. 2001. The NBER patent citation data file: lessons, insights, and methodological tools. CEPR Discussion Paper 3094.

Hardy Q. 2002. Search 500,000 documents, review 160,000 pages in 20 hours, and then do it all over again: the detailed life of a patent examiner. Forbes 169(14): 50.

Harhoff D, Narin F, Scherer FM, Vopel K. 1999. Citation frequency and the value of patented inventions. Review of Economics and Statistics 81(3): 511-515.

Jensen M, Meckling WH. 1976. Theory of the firm: managerial behavior agency costs and ownership structure. Journal of Financial Economics 3: 305-360.

John K, Lang LHP. 1991. Insider trading around dividend announcements - theory and evidence. Journal of Finance 46(4): 1361-1389. 
Karpoff JM, Lee D. 1991. Insider trading before new issue announcements. Financial Management 20(1): $18-26$.

Ke B, Huddart S, Petroni K. 2003. What insiders know about future earnings and how they use it: evidence from insider trades. Journal of Accounting and Economics 35(3): 315-346.

Kogut B, Zander U. 1992. Knowledge of the firm, combinative capabilities, and the replication of technology. Organization Science 3(3): 383-397.

Lanjouw JO, Pakes A, Putnam J. 1998. How to count patents and value intellectual property: the uses of patent renewal and application data. Journal of Industrial Economics 46(4): 405.

Lanjouw JO, Schankerman M. 1999. The quality of ideas: measuring innovation with multiple indicators. NBER Working Paper 7345.

Lee PM. 2001. What's in a name.com?: the effects of '.com' name changes on stock prices and trading activity. Strategic Management Journal 22(8): $793-804$.

Levinthal DA, March JG. 1993. The myopia of learning. Strategic Management Journal, Winter Special Issue 14: $95-112$.

Lippman SA, Rumelt RP. 1982. Uncertain imitability: an analysis of interfirm differences in efficiency under competition. Bell Journal of Economics 13(2): $418-438$.

Long C. 2002. Patent signals. University of Chicago Law Review 69(2): 625-679.

McGrath RG. 1997. A real options logic for initiating technology positioning investments. Academy of Management Review 22(4): 974-996.

Milgrom P, Roberts J. 1992. Economics, Organization and Management. Prentice-Hall: Englewood Cliffs, NJ.

Miller MJ. 2001. Michael J. Miller and Bill Gates: uncut. PC Magazine 4 September. http://www.pcmag.com/ article12/10,1759,35768,35700.asp $\quad[18$ February 2005].

Mosakowski E. 1997. Strategy making under causal ambiguity: conceptual issues and empirical evidence. Organization Science 8(4): 414-442.

Myers SC, Majluf NS. 1984. Corporate financing and investment decisions when firms have information that investors do not have. Journal of Financial Economics 13(2): 187-221.
Narin F, Carpenter MP, Woolf P. 1984. Technological performance assessments based on patents and patent citations. IEEE Transactions on Engineering Management 31(4): 172-183.

Nonaka I. 1994. A dynamic theory of organizational knowledge creation. Organization Science 5(1): 14-37.

Polanyi M. 1962. Personal Knowledge: Towards a PostCritical Philosophy. Harper \& Row: New York.

Prahalad CK, Hamel G. 1990. The core competence of the corporation. Harvard Business Review 68(3): 79-91.

Reed R, DeFillippi RJ. 1990. Causal ambiguity, barriers to imitation, and sustainable competitive advantage. Academy of Management Review 15(1): 88-102.

Rumelt RP, Schendel D, Teece DJ. 1991. Strategic management and economics. Strategic Management Journal, Winter Special Issue 12: 5-29.

Securities and Exchange Commission. 2002. Insider trading: information on bounties. Securities and Exchange Commission. http://www.sec.gov/divisions/enforce/ insider.htm [20 August 2002].

Seyhun HN. 1986. Insiders' profits, costs of trading, and market-efficiency. Journal of Financial Economics 16(2): 189-212.

Seyhun HN. 1990. Overreaction or fundamentals: some lessons from insiders' response to the market crash of 1987. Journal of Finance 45(5): 1363-1388.

Seyhun HN. 1992. Why does aggregate insider trading predict future stock returns. Quarterly Journal of Economics 107(4): 1303-1331.

Teece DJ. 1986. Profiting from technological innovation: implications for integration, collaboration, licensing, and public policy. Research Policy 15: 285-305.

Teece DJ, Pisano G, Shuen A. 1997. Dynamic capabilities and strategic management. Strategic Management Journal 18(7): 509-533.

Trajtenberg M. 1990. A penny for your quotes: patent citations and the value of innovations. Rand Journal of Economics 21(1): 172-188.

U.S. Patent and Trademark Office. 2002. TAF Special Report: all patents, all types-January 1977-December 2001.

U.S. Patent and Trademark Office. 2003. Private interview conducted on Tuesday January 28th, 2003. 